\title{
POLLEN AND CHARCOAL ANALYSES FROM LAKE ETU-MUSTAJÄRVI, SOUTHERNFINLAND, WITH SPECIAL REFERENCE TO AN EARLY HOLOCENE URTICA POLLEN MAXIMUM
}

\author{
KAARINA SARMAJA-KORJONEN
}

SARMAJA-KORJONEN, KAARINA 1995:Pollen and charcoal analyses from Lake Etu-Mustajärvi, Southern Finland, with special reference to an early Holocene Urtica pollen maximum. Bull. Geol. Soc. Finland 67, Part 1, 37-46.

Sediments of a small lake, Etu-Mustajärvi, in southern Finland, were studied with respect to their fossil pollen and charcoal content. Pollen analysis showed a typical development of vegetation from the earliest Holocene onwards, since the isolation of the lake from the Baltic Ice Lake. The emerged land was first colonised by herbs and bushes, and for the first time in Finland an Urtica maximum of $4 \%$ is reported for this period. It is considered possible that Urtica may have been a commoner part of the pollen flora of newly emerged land in south Finland than has been previously thought. Charcoal analysis was undertaken to examine the Holocene history of forest fires in the area. At least in the Lammi area, charcoal seems to have been most abundant about $8000-6000 \mathrm{BP}$, a result which is in apparent disagreement with the general concept that the period was moist and thus forest fire frequency could not have been high.

Key words: paleoecology, lake sediments, paleobotany, pollen analysis, Urtica, charcoal, fires, Holocene, Lammi, Finland

Kaarina Sarmaja-Korjonen: Division of Geology and Palaeontology, Department of Geology, University of Helsinki, P.O. Box 11, FIN-00014 University of Helsinki, Finland 


\section{INTRODUCTION}

Although the development of vegetation from the early Holocene onwards has been widely studied in Finland (e.g. Donner 1966, Hyvärinen 1972, Alhonen \& Vuorela 1974, Korhola \& Tikkanen 1992), pollen analysis has generally not been combined with charcoal analysis, with one exception (Tolonen 1980). Charcoal analysis has been mainly limited to studies of human impact and clearence with fire (e.g. Tolonen 1978, 1985a, Huttunen 1980, Grönlund \& Asikainen 1992, Sarmaja-Korjonen 1992). Thus the history of fire during the earlier Holocene is not well known.

A lake, Etu-Mustajärvi, from Lammi, southern Finland was selected for pollen and charcoal analyses. Its sediment covers the entire Holocene. The aim of the study was to examine in parallel with the development of vegetation, whether there are any noticeable trends in the amounts of microscopic charcoal during the different stages of the Holocene. Thus a general background for further forest fire frequency studies can be achieved.

\section{THE SITE}

Etu-Mustajärvi is situated between the First and Second Salpausselkä end-moraines, in the parish of Lammi, southern Finland (Fig. 1). It is a small basin (ca 4.5 ha) surrounded by a mire, Mustajärvensuo. A sediment core from the shore of another basin in the same mire, Lake Taka-Mustajärvi, was studied by Okko (1957).

The elevation of the site is $158.1 \mathrm{~m}$ above the sea level and the water depth was $9 \mathrm{~m}$ at the coring point. The level of the Baltic Ice Lake was about $160 \mathrm{~m}$ a.s.l. in the area (Okko 1957). The lake became isolated during the drainage of the Baltic Ice Lake about $10300 \mathrm{BP}$. The change is also seen in the diatom composition (analysed by Heikki Haila) where the species common in a large lake drastically changed into small lake forms.

\section{SAMPLING AND LABORATORY TREATMENT}

Coring was undertaken in March 1989 with a Livingstone corer near the center of the lake. The water depth was $9 \mathrm{~m}$. The stratigraphy was as follows:

0-170 $\mathrm{cm}$ dark brown gyttja

$170-200 \mathrm{~cm}$ a gradual change from gyttja to claygyttja

$200 \mathrm{~cm}$ a layer of moss remains (Drepanocladus) $200-220 \mathrm{~cm}$ silty clay

$220-240 \mathrm{~cm}$ sand

240-255 cm silty sand

Pollen was analysed only from $195 \mathrm{~cm}$ upwards since the lower sediment was non-polleniferous. Samples of $0.5 \mathrm{~cm} 3$ were taken for pollen analysis and treated with the $\mathrm{KOH}, \mathrm{HF}$ and acetolycis methods (Fægri \& Iversen 1989), HF and acetolycis only for the lowermost samples with high minerogenic content. 1000 or more pollen grains were counted from each sample except the lowest samples which were poor in pollen. Lycopodium tablets were added for estimates of the pollen concentration (Stockmarr 1971). The basic sum for land pollen percentages is AP + NAP (Total Pollen), for aquatic pollen AquP + Total Pollen and for spores the spore sum + Total Pollen.

Microscopic charcoal particles were counted according to the method described by Sarmaja-Korjonen (1992) but only in four size groups, 65, 225, 450 and 450-3200 $\mu \mathrm{m}^{2}$. Charcoal particles were counted only from $170 \mathrm{~cm}$ upwards because in the lowermost samples there was a high proportion of black suphide which made the identification uncertain. The nomenclature of the vascular plants is according to Hämet-Ahti et al. (1986). 

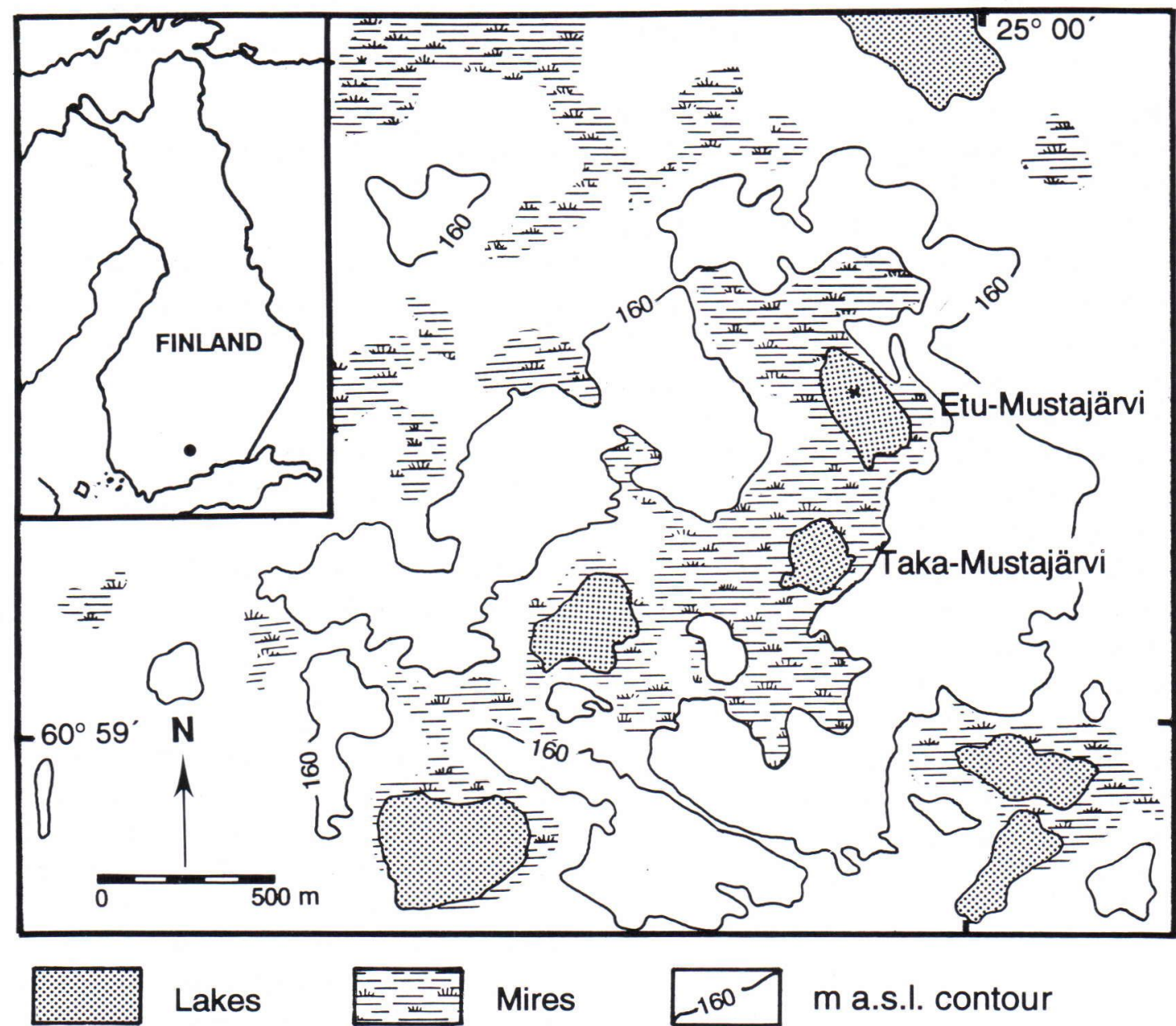

Fig. 1. Location of the study site, Etu-Mustajärvi, in the parish of Lammi, southern Finland. The sampling point is marked with a cross.

\section{RESULTS}

EMJ la (195-180 cm) Betula-NAP local paz

The zone (Fig. 2) is characterized by growing Betula values and high (40\% of the total pollen sum) NAP values. At the beginning of the zone some Alnus, Corylus, Ulmus and Quercus pollen are found, most certainly representing redeposited pollen. The main NAP components are Salix, Juniperus, Cyperaceae, Poaceae, Chenopodiaceae,
Rumex acetosa/acetosella type, Artemisia, Thalictrum and Urtica which is present with a maximum of $4 \%$ at $190 \mathrm{~cm}$. Also Lycopodium is abundant. Towards the upper part of the zone Empetrum, Ericaceae and Ranunculaceae rise. Concentration (Fig. 3) of Betula is very low.

Because the Urtica values were exceptionally high at $195 \mathrm{~cm}, 8$ extra $1 \mathrm{~cm}$ thick samples were analysed around the maximum. The Urtica values varied from $1.5 \%$ to $5.4 \%$ in these samples. 


\section{ETU-MUSTAJÄRVI}

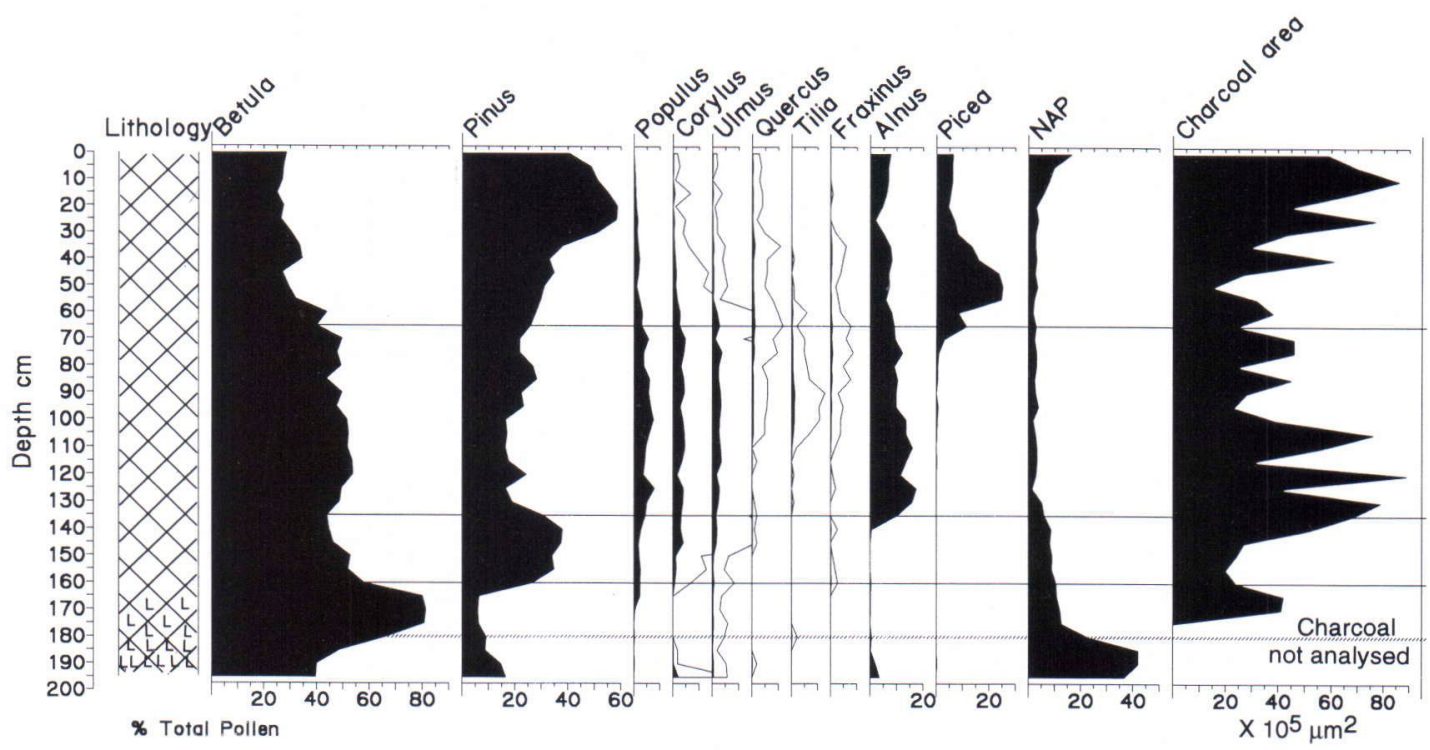

Fig. 2. Relative pollen diagram of Lake Etu-Mustajärvi, southern Finland.

\section{EMJ $1 b(180-160 \mathrm{~cm})$ Betula local paz}

The zone boundary at $180 \mathrm{~cm}$ is defined by a further rise in Betula values and decrease in NAP to about $15 \%$. Thalictrum, Myriophyllum alterniflorum, Potamogeton, Equisetum and Polypodiaceae characterize the zone. Urtica does not reach values over $1 \%$, while Humulus pollen begins to be reported continuously. At the upper part of the zone Populus, Corylus and Fraxinus appear. Concentrations of Betula and Pinus are still low.

\section{EMJ 2 (160-135 cm) Pinus local paz}

The lower zone boundary is defined by the decline of Betula and a rapid rise of Pinus. Populus, Corylus and Ulmus are present. In terms of NAP Salix, Juniperus, Cyperaceae and Poaceae occur throughout the zone at steady values (2-4\%). The zone is also characterized by high values of
Isoktes. Charcoal particle area remains relatively low in the lower part of the zone but rises rapidly towards the top. Concentration of Pinus strarts to rise.

\section{EMJ 3 (135-65 cm) Betula-Alnus-Corylus-}

Ulmus local paz

The zone boundary at $135 \mathrm{~cm}$ is defined by a rapid decrease in Pinus and rise in Alnus. Quercus, Tilia and Fraxinus rise slightly. Just above the lower zone boundary the total NAP values decline below $5 \%$ and remain low for the rest of the zone. Salix, Juniperus, Cyperaceae and Poaceae are steadily present but with values of about $1 \%$. Urtica, Humulus, Artemisia and Filipendula are continously present. The zone is also characterized by the presence Pteridium. Charcoal is abundant in the lower part of the zone and declines in the upper one. Concentrations are at their highest in this zone. 


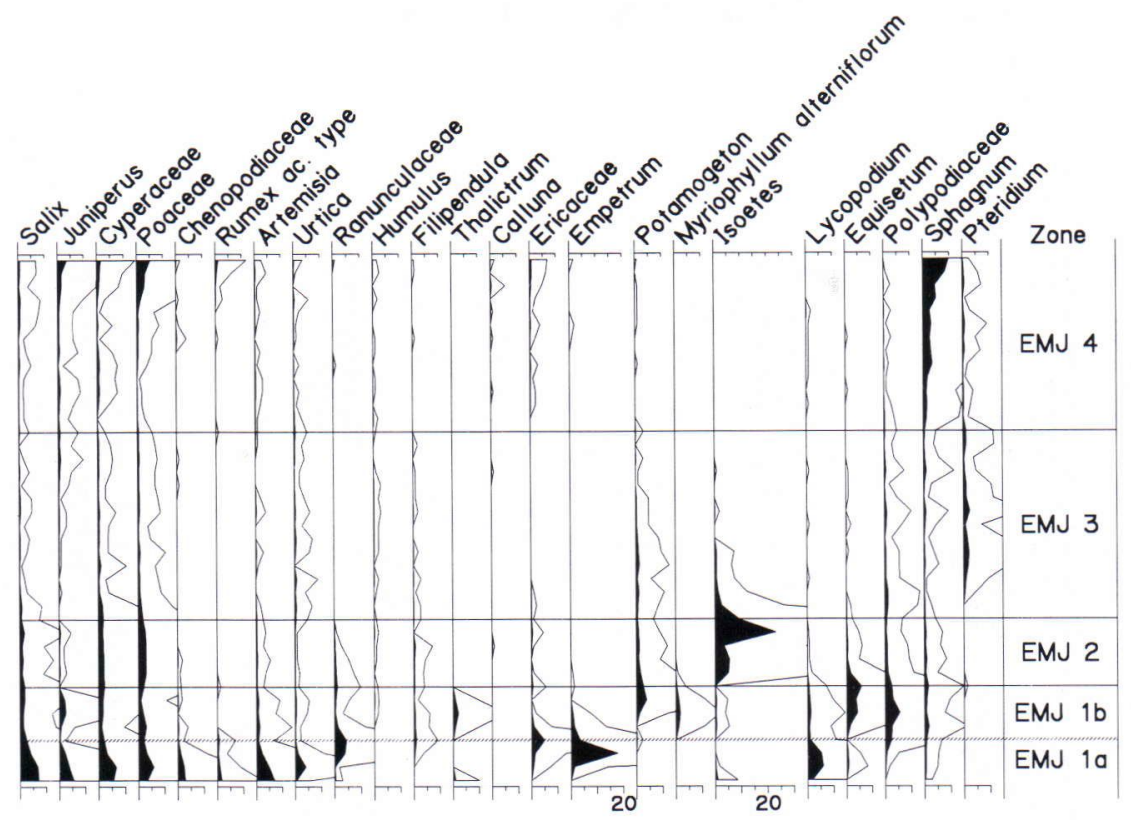

\% Total Pollen

EMJ $4(65-0 \mathrm{~cm})$ Picea-Pinus local paz

The zone boundary is defined mainly by the rise in Picea. Betula starts to decrease as Pinus increases. The decline of Populus, Corylus, Ulmus, Quercus, Tilia and Fraxinus is gradual. NAP values rise towards the top. Concentrations follow the same pattern as the percentage curves of the trees.

\section{DISCUSSION}

The pollen stratigraphy (Fig. 2) shows the development of vegetation in Holocene wellknown from earlier studies from southern Finland (e.g. Donner 1972, Tolonen \& Ruuhijärvi 1976,
Donner et al. 1978). After the basin was isolated from the Baltic Ice Lake its surroundings were rapidly colonized by bushes, herbs and pteridophytes, such as Salix, Juniperus, Cyperaceae, Artemisia, Chenopodiaceae, Rumex, Urtica and Lycopodium. The basin is situated on an large elevated area which emerged early and offered habitats for the early vegetation.

The birch forest that followed (EMJ 1b) was relatively open and light as indicated by the still rather high NAP values. Also Equisetum and Polypodiaceae were present. Salix, Cyperaceae and Poaceae did not decrease markedly in the pine forest phase (EMJ 2), not until after the more closed broad-leaved forest was established (zone EMJ 2/EMJ 3 transition). Pteridium appears to have been a typical element in the broad-leaved forests as it is commonly abundant in this phase in pollen diagrams from southern Finland (e.g. Vuorela 1978, 1981, 1983, Tolonen 1985b). 


\section{ETU-MUSTAJÄRVI Concentrations}

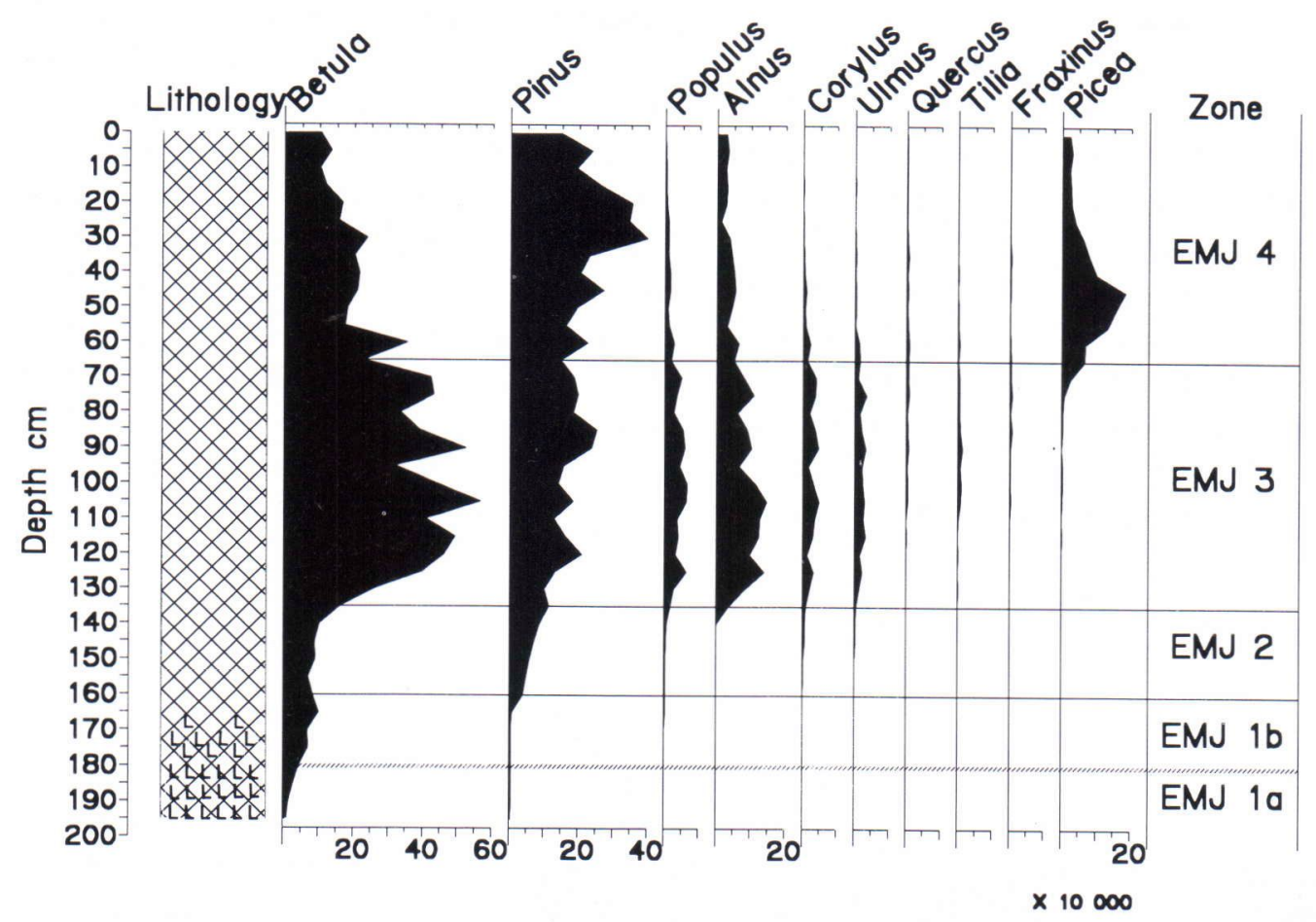

Fig. 3. Lake Etu-Mustajärvi, southern Finland. Pollen concentrations of trees.

After the spread of spruce (zone EMJ 3/EMJ 4 transition) the broad leaved trees declined gradually. The rise of NAP near the top of the diagram can be connected to human activities (the first cereal pollen grain was found at $35 \mathrm{~cm}$ ). Various studies from the Lammi area and neighboring areas have shown that intensive clearance and cultivation was practised from the Iron Age onwards (e.g. Tolonen 1978, 1980, Huttunen 1980).

The local pollen assemblage zones of EtuMustajärvi correspond well with the regional pollen assemblage zones suggested by Donner (1971). There are numerous radiocarbon dates from Lammi and the neighbouring areas for different events of forest history (listed in Tolonen \& Ruuhijärvi 1976, Donner et al. 1978). According to them the transition of the Birch and Pine zones (EMJ Ib/EMJ2) is about 9000 radiocarbon years and the limit between the Pine zone and the Birch-alder-hazel-elm zone (EMJ2/ EMJ3) about 8000 radiocarbon years. Picea spread to the Lammi area about 4500 BP (Tolonen \& Ruuhijärvi 1976, see also Tolonen 1980). 
The local pollen assemlage zones, age estimations and chronozones (sensu Mangerud et al. 1974) are shown in Fig. 4.

\section{Urtica}

Among the typical herb pollen flora of newly emerged land in early Holocene (Artemisia, Chenopodiaceae, Rumex) the maximum of $4 \%$ of Urtica pollen is a feature never before reported in Finnish pollen diagrams before, although some sporadic finds have been reported (e.g. Alhonen \& Vuorela 1974, Tolonen 1980, Bondestam et al. 1994). In northwestern Europe and Scandinavia seeds and pollen of Urtica have been found also in Late Glacial and preboreal sediments (Bohncke et al. 1987, Paus 1988, 1989, Oeggl \& Eicher 1989). According to Godwin (1975) Urtica was present in the 'tall-herb' communities in the Weichselian lowland landscape in Britain.

When a peak in a pollen taxon in just one sample is found, the possibility of flower or insect contamination in the sediment cannot be ruled out. In the present case, however, the high amounts of Urtica pollen in the extra samples suggest that this is not a case of contamination. Two explanations are plausible. First, that Etu-Mustajärvi was a special site around which Urtica was present in early Holocene unlike lakes in previous studies. Secondly, that Urtica pollen may not have been noticed earlier in early Holocene samples. The sediments of this period are usually rich in minerogenic matter and need HF treatment which seems to shrink pollen grains. The pores are then hardly visible on the very small pollen grain, even at magnification of 400 in microscope.

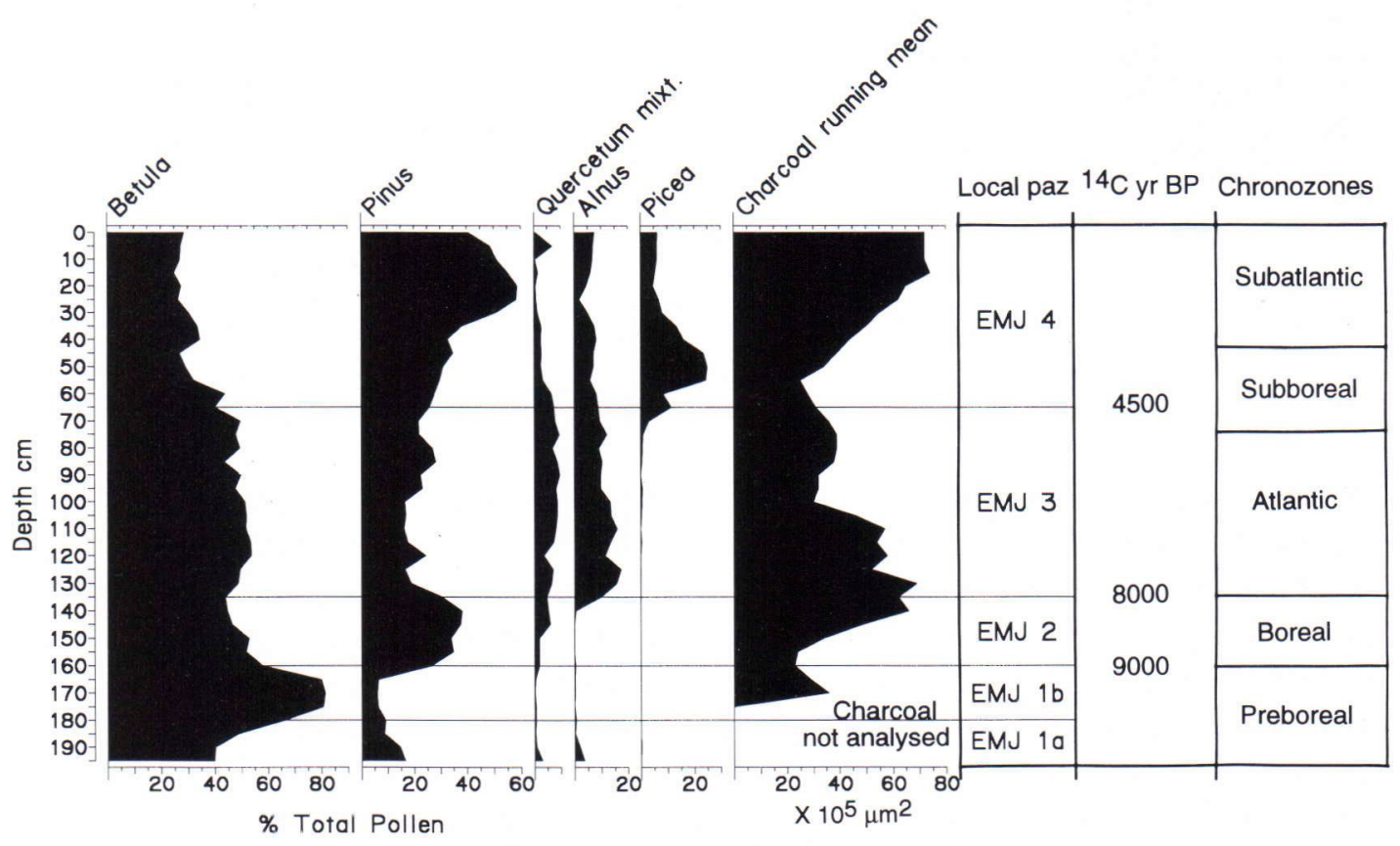

Fig. 4. The main tree pollen curves and the running mean for charcoal area (3 samples) obtained from Lake Etu-Mustajärvi, S Finland. The time scale is approximate and adapted from other studies (see text). 
Since the identification of Urtica pollen grains has become more common in Finland, it has appeared an inseparable component of the seashore pollen flora (M. Tolonen 1983, Sarmaja-Korjonen et al. 1991, Sarmaja-Korjonen 1992), as well as the damp groves around lakes (Sarmaja-Korjonen 1992) during the Holocene. The latter case is also shown in Etu-Mustajärvi by the continuous occurrences of Urtica along with Humulus above the early maximum. It is also possible that Urtica was a commoner component of the southern Finnish flora of newly emerged land in Early Holocene than has been considered earlier. This possibility is also suggested by studies from Vihti, southern Finland (Sarmaja-Korjonen, in prep.). Further studies are needed to clarify this problem.

\section{Charcoal record and forest fires}

Charcoal was analysed to derive a general forest fire history and to see if there are any clear trends during the different forest phases of the Holocene. Sample thickness was $5 \mathrm{~cm}$ and therefore not adequate to find individual forest fires as can be done with more detailed analysis methods (e.g. Sarmaja-Korjonen 1992). Therefore the charcoal area is also shown by a running mean curve (Fig. 4).

The charcoal area is not very large during the end of the Preboreal and rises sharply towards the end of the Boreal. It stays high during the first half of the Atlantic period, up to about $6000 \mathrm{BP}$, after which it decreases and stays low till the end of the Subboreal. Then it rises again, after the spread of spruce, and according to many studies (Tolonen 1978, Huttunen 1980, K. Tolonen 1983) this is due to two facts. First, the new forests where spruce was very common burned easily and secondly, the practice of clearance increased in the Lammi area from the Iron Age onwards.

According to the present results fires were more common during the first half of the Atlantic period than the second. By comparison, lake levels in southern Sweden were at their highest around $7000 \mathrm{BP}$ and the time between 8000-6000 has been considered moist (Digerfeldt 1988, Harrison \& Digerfeldt 1993). In Finland lake levels rose towards the beginning of the Atlantic period (Alhonen 1972, Donner et al. 1978, Korhola \& Tikkanen 1991). A drier period followed from about 6000-3000 (Digerfeldt 1988, Harrison \& Digerfeldt 1993). At least in the Lammi area, fires seem to have been more common during the moist period than the following drier one. This is supported by the results of Tolonen (1980) from Lake Lamminjärvi where she got almost identical behaviour of the charcoal curve. These two charcoal analyses are the only ones covering the whole Holocene done so far in Finland and the controversy can be explained only by further and more detailed studies.

ACKNOWLEDGEMENTS: The fieldwork was done by Prof. Joakim Donner, Mr. Peter Voss, and Mr. Heikki Haila. Heikki Haila also analysed the diatoms and did the loss-on-ignition determinations. Dr. Marjatta Aalto kindly identified the moss sample. I wish to express my sincere thanks to all of them. I am also most grateful to Dr. Mirjami Tolonen and Dr. Keith Bennett for critical comments on the manuscript and to Dr. Chronis Tzedakis who made helpful suggestions and checked the English. I greatly appreciate the financial support given me by the Ella and Georg Ehrnrooth Foundation. 


\section{REFERENCES}

Alhonen, P. 1972. Galltrdsket: The geological development and palaeolimnology of a small polluted lake in Southern Finland. Commentationes Biologicae 57, 1-34.

Alhonen, P. \& Vuorela, I. 1974. Lamminjdrven kerrostumien siitepvly-ja piilevdstratigrafia (Summary: On the pollen and diatom stratigraphy of the Flandrian sediments of Lamminjärvi, Southern Finland). Luonnon Tutkija 78, 40-47.

Bohncke, S., Vandenberghe, J., Coope, R. \& Reiling, $R$. 1987. Geomorphology and palaeoecology of the Mark Valley (southern Netherlands): palaeoecology, palaeohydrology and climate during the Weichselian Late Glacial. Boreas 16, 69-85.

Bondestam, K., Vasari, A., Vasari, Y., Lemdahl, G. \& Eskonen, K. 1994. Younger Dryas and Preboreal in Salpausselkd foreland, Finnish Karelia. In: Lotter, A.F. \& Amman, B. (eds.), Festschrift Gerhard Lang. Dissertationes Botanicae 234, 161-206.

Digerfeldt, G. 1988. Reconstruction and regional correlation of Holocene lake-level fluctuations in Lake Bysjön, South Sweden. Boreas 17, 165-182.

Donner, J.J. 1966. The Late-glacial and early Post-glacial pollen stratigraphy of southern and eastern Finland. Commentationes Biologicae 29, 1-24.

Donner, J. 1971. Towards a stratigraphical division of the Finnish Quaternary. Commentationes PhysicoMathematicae 41, 281-305.

Donner, J. 1972. Pollen frequencies in the Flandrian sediments of Lake Vakojärvi, south Finland. Commentationes Biologicae 53, 1-19.

Donner, J.J., Alhonen, P., Eronen, M., Jungner, H. \& Vuorela, I. 1978. Biostratigraphy and radiocarbon dating of the Holocene lake sediments of Tyvtjärvi and the peats in the adjoining bog Varrassuo west of Lahti in southern Finland. Annales Botanici Fennici 15, 258-280.

Fagri, K., Iversen, J. 1989. Textbook of pollen analysis. John Wiley \& Sons Ltd. IV Edition. 328 pp.

Godwin, H. 1975. The history of the British flora. Cambridge University Press. Cambridge. $541 \mathrm{pp}$.

Grönlund, E. \& Asikainen, E. 1992. Local agricultural history of Saario village (Tohmajärvi, north Karelia) since 1607 AD - a palaeoecological approach. In: Grönlund, E. (ed.), The first meeting of Finnish palaeobotanists; state of the art in Finland - May 2-4. 1990. University of Joensuu, Publications of Karelian Institute 102, 61-74.

Harrison, S.P. \& Digerfeldt, G. 1993. European lakes as palaeohydrological and palaeoclimatic indicators. Quaternary Science Reviews 12, 233-248.

Huttunen, $P$. 1980. Early land use, especially the slashand-burn cultivation in the commune of Lammi, southern Finland, interpreted mainly using pollen and charcoal analyses. Acta Botanica Fennica 113, 1-45.
Hyvärinen, H. 1972. Flandrian regional pollen assemblage zones in eastern Finland. Commentationes Biologicae $59,1-25$.

Hämet-Ahti, L., Suominen, J., Ulvinen, T., Uotila, P. \& Vuokko, S. (eds) 1986. Retkeilykasvio. 3rd rev. ed. Suomen Luonnonsuojelun Tuki Oy, Helsinki. 598 pp.

Korhola, A.A. \& Tikkanen, M.J. 1991. Holocene development and early extreme acidification in a small hilltop lake in southern Finland. Boreas 20, 333-356.

Korhola, A. \& Tikkanen, M. 1992. The lateglacial - early postglacial transition in the pollen stratigraphy of Lake Pieni Majaslampi, Espoo, southern Finland. In: Grönlund, E. (ed.), The first meeting of Finnish palaeobotanists; state of the art in Finland - May 2-4. 1990. University of Joensuu, Publications of Karelian Institute 102, 85-98.

Mangerud, J., Andersen, S.T., Berglund B.E. \& Donner, J.J., 1974. Quaternary stratigraphy of Norden, a proposal for terminology and classification. Boreas 3 , 109-128.

Oeggl, K. \& Eicher, U. 1989. Pollen and oxygen-isotope analyses of late- and postglacial sediments from the Schwemm raised bog near Walchsee in Tirol, Austria. Boreas 18, 245-253.

Okko, V. 1957. The Second Salpausselkä at Jylisjärvi, east of Hämeenlinna. Fennia 81, 1-46.

Paus, A. 1988. Late Weichselian vegetation, climate, and floral migration at Sandvikvatn, North Rogaland, southwestern Norway. Boreas 17, 113-139.

Paus, A. 1989. Late Weichselian vegetation, climate, and floral migration at Liastemmen, North Rogaland, southwestern Norway. Journal of Quaternary Science 4, 223242.

Sarmaja-Korjonen, K. 1992. Fine-interval pollen and charcoal analyses as tracers of early clearance periods in S Finland. Acta Botanica Fennica 146, 1-75.

Sarmaja-Korjonen, K., Vasari, Y. \& Haggström, C.-A. 1991. Taxus baccata and influence of Iron Age man on the vegetation in Aland, SW Finland. Annales Botanici Fennici 28, 143-159.

Stockmarr, J. 1971. Tablets with spores used in absolute pollen analysis. Pollen et Spores 13, 615-621.

Tolonen, K. 1983. The post-glacial fire record. In: Wein, R.W. and MacLean, D.A. (eds), The role of fire in northern circumpolar ecosystems, 21-44. John Wiley $\&$ Sons Ltd.

Tolonen, K. \& Ruuhijärvi, R. 1976. Standard pollen diagrams from the Salpausselkä region of Southern Finland. Annales Botanici Fennici 13, 155-196.

Tolonen, M. 1978. Palaeoecology of annually laminated sediments in Lake Ahvenainen, S. Finland. I. Pollen and charcoal analyses and their relation to human impact. Annales Botanici Fennici 15, 177-208. 
Tolonen, M. 1980. Postglacial pollen stratigraphy of Lake Lamminjärvi, S. Finland. Annales Botanici Fennici 17, 15-25.

Tolonen, M. 1983. Late Holocene vegetational history in Salo, Pukkila, SW Finland, with particular reference to human interference. Annales Botanici Fennici 20, $157-$ 168.

Tolonen, M. 1985a: Palaeoecological record of local fire history from a peat deposit in SW Finland. Annales Botanici Fennici 22, 15-29.

Tolonen, M. 1985b. Palaeoecological reconstruction of vegetation in a prehistoric settlement area,
Salo, SW Finland. Annales Botanici Fennici 22, 101-116.

Vuorela, I. 1978. Local settlement history of Lahti area as shown by pollen analysis. Bulletin of the Geological Society of Finland 50, 45-57.

Vuorela, I. 1981. The vegetational and settlement history in Sysmä, central South Finland, interpreted on the basis of two pollen diagrams. Bulletin of the Geological Society of Finland 53, 47-61.

Vuorela, I. 1983. Vohtenkellarinsuo, a bog in Paimio, SW Finland with a cultural origin. Bulletin of the Geological Society of Finland 55, 57-66. 